\title{
Learning in advance? Interspecific recognition ability in male Eurasian blackcaps
}

\author{
Piotr Matyjasiak ${ }^{1}$ (1)
}

Received: 15 February 2021 / Revised: 29 April 2021 / Accepted: 14 May 2021 / Published online: 28 May 2021

(c) The Author(s) 2021

\begin{abstract}
Interspecific aggression is common in bird communities. It is thought to be a consequence of learned behavior or misdirected intraspecific aggression. In the former case birds acquire the ability to identify individuals of other species by social learning of species-specific traits during interactions with heterospecifics in a shared habitat. I conducted a two-choice song playback experiment to investigate the role of associating signals from two sensory modalities, auditory and visual, in shaping the agonistic response of male Eurasian Blackcaps (Sylvia atricapilla) to simulated male Garden Warbler (S. borin) intruders. I measured focal males' response to playbacks to the song of a Blackcap or a Garden Warbler while giving them a choice between stuffed male models of both species presented in their territories. The experiments were carried out in early spring, before the arrival of Garden Warblers from Africa. I found that male Blackcaps were able to associate species-specific songs with species-specific plumage types. The ability to associate signals characterized not only experienced after-second-year old males, but also second-year old males that had not had the opportunity to defend breeding territories against heterospecifics. This suggests that second-year old male Blackcaps acquire the ability to associate Garden Warbler song with plumage before they use this skill when defending territory during their first breeding episode. Male Blackcaps do not mistake male Garden Warblers for males of their species, but rather learn these associations during the first months of life. However, the possibility that these associations are innate cannot be excluded.
\end{abstract}

Keywords Interspecific competition $\cdot$ Playback experiment $\cdot$ Species coexistence $\cdot$ Species interactions $\cdot$ Sylvia atricapilla . Territoriality

Communicated by F. Bairlein.

Piotr Matyjasiak

pmatyjasiak@wp.pl

1 Institute of Biological Sciences, Cardinal Stefan Wyszyński

University in Warsaw, Wóycickiego 1/3, 01-938 Warsaw,

Poland 


\section{Zusammenfassung}

\section{Lernen im Voraus? Interspezifische Erkennungsfähigkeit bei männlichen Mönchsgrasmücken}

Interspezifische Aggression ist in Vogelgemeinschaften weit verbreitet. Man geht davon aus, dass es sich um ein erlerntes Verhalten oder um fehlgeleitete intraspezifische Aggression handelt. Im ersten Fall erwerben Vögel die Fähigkeit, Individuen anderer Arten durch soziales Lernen von artspezifischen Merkmalen während Interaktionen mit den anderen Arten in einem gemeinsamen Lebensraum zu identifizieren. Ich führte ein Zwei-Wahl Playbackexperiment durch, um die Rolle der Assoziation von Signalen aus zwei Sinnesmodalitäten, auditiv und visuell, bei der Gestaltung der agonistischen Reaktion von männlichen Mönchsgrasmücken (Sylvia atricapilla) auf simulierte männliche Gartengrasmücken (S. borin) zu untersuchen. Ich habe die Reaktion der fokalen Männchen auf das Playback des Gesangs einer Mönchsgrasmücke oder einer Gartengrasmücke gemessen, während ich ihnen die Wahl zwischen ausgestopften männlichen Modellen beider Arten gab, die in ihrem Territorium präsentiert wurden. Die Versuche wurden im zeitigen Frühjahr durchgeführt, also vor der Ankunft der Gartengrasmücke aus Afrika. Ich fand heraus, dass männliche Mönchsgrasmücken in der Lage waren, artspezifische Gesänge mit artspezifischen Gefiedertypen zu assoziieren. Die Fähigkeit, Signale zu assoziieren, zeignete nicht nur erfahrene nach-, sondern auch zweijährige Männchen aus, die noch nicht die Gelegenheit gehabt hatten, Brutreviere gegen Heterospezies zu verteidigen. Dies deutet darauf hin, dass zweijährige männliche Mönchsgrasmücken die Fähigkeit erwerben, den Gesang der Gartengrasmücke mit dem Gefieder zu assoziieren, bevor sie diese Fähigkeit bei der Verteidigung des Territoriums während ihrer ersten Brutepisode einsetzen. Männliche Mönchsgrasmücken verwechseln männliche Gartengrasmücken nicht mit Männchen ihrer Art, sondern lernen diese Assoziationen in den ersten Lebensmonaten. Die Möglichkeit, dass diese Assoziationen angeboren sind, kann jedoch nicht ausgeschlossen werden.

\section{Introduction}

Interspecific aggression is widespread in birds and other taxa (including damselflies, ants, reef fish, salamanders, lizards and mammals) and often takes the form of territoriality (Orians and Willson 1964; Grether et al. 2009; Ord and Stamps 2009; Peiman and Robinson 2010; Ord et al. 2011). Aggressive interactions between heterospecifics influence habitat partitioning, species coexistence, range limits and local extinctions, thus having major ecological outcomes (Robinson and Terborgh 1995; Jankowski et al. 2010; Peiman and Robinson 2010; Losin et al. 2016; Freeman et al. 2019). Furthermore, they may drive phenotypic evolution, in particular the evolution of mechanisms to distinguish between different classes of competitors and non-competitors, and phenotypic traits related to species recognition (Irwin and Price 1999; Grether et al. 2009, 2013, 2017; Tobias et al. 2014; Martin et al. 2015; Drury et al. 2020; Simpson et al. 2021). When it occurs, interspecific aggression is thought to be (i) a learned response to the presence of other species (the 'learned interspecific aggression' hypothesis), (ii) a consequence of misdirected intraspecific aggression (the 'mistaken identity' hypothesis), (iii) an evolved interference response to interspecific competition (the 'innate interspecific recognition hypothesis', or a combination of these mechanisms.

The 'learned interspecific aggression' mechanism involves a plastic response to the presence of heterospecific competitors for limited resources (Irwin and Price 1999; Peiman and Robinson 2010). Individuals may learn to recognize heterospecifics in areas where the other species coexists. As a result, the interspecific aggressive response may be strong in sympatry and weak or non-existent in allopatry (Emlen et al. 1975; Catchpole 1978; Reed 1982; Gil 1997; Sedláček et al. 2006). Significant differences in interspecific response between sympatric and allopatric areas were observed in cases where these areas were a few kilometers or even just a few hundred meters apart (Catchpole and Leisler 1986; Prescott 1987; Freeman 2016; Freeman et al. 2016). It was suggested that individuals may learn to recognize heterospecifics by making associations between different forms of signals (vocalizations, coloration, morphology and displays), and then use one of these signals to recognize individuals that vary in others (Gill and Murray 1972; Irwin and Price 1999; Price 2008; Grether 2011). The ability to make associations can be expected in individuals that have interacted with heterospecifics during resource defense, but not in those that have not.

According to the 'mistaken identity' hypothesis, interspecific territorial aggression arises when two species that (because of close phylogenetic relatedness or chance) share similar traits that stimulate intraspecific territorial aggression come into contact (Murray 1971, 1981). Due to the similarity of traits releasing intraspecific response (e.g. vocalizations, coloration or displays), heterospecifics may be misidentified as conspecifics (Petrusková et al. 2008; Wolfenden et al. 2015; McEntee 2014; Jones et al. 2016). If these two species do not compete with each other for limited resources, costs of misdirected interspecific aggression may trigger the selection for divergence in these traits, resulting in the disappearance of interspecific response in sympatry (Grether et al. 2009). Otherwise, in sympatry benefits of mutual recognition may select for convergence in competitor recognition traits in these species (e.g. Reif et al. 2015). 
Interspecific discrimination based on the association of species-specific traits is not to be expected in this case.

The 'innate species recognition' may result from genetic assimilation of species recognition templates - an evolutionary response to the cost of learning (Irwin and Price 1999; Price 2008; Grether et al. 2009). This cost may be the time required to learn about heterospecifics in the first ever breeding episode. Innate recognition can accelerate learning, thus reducing the time cost. It is suggested that the ability of birds to innately associate species-specific traits cannot be ruled out either (Grether 2011). If this is the case, then interspecific discrimination based on associations of speciesspecific traits should occur regardless of prior experience with heterospecifics.

Here, with a two-choice song playback experiment utilizing stuffed male models, I investigated the role of associative learning of signals from two sensory modalities (auditory and visual systems) in shaping the interspecific response of male Eurasian Blackcaps (Sylvia atricapilla) to simulated male Garden Warbler (S. borin) intruders to their territories. Eurasian Blackcap males respond aggressively to playbacks of songs of many sympatric species of Sylvia warblers, but the reaction to the singing of the Garden Warbler is the strongest (Darolová et al. 2020). Blackcaps and Garden Warblers both are widely sympatric in most of Europe, resemble each other in song and morphology and have similar ecological requirements, but Garden Warblers overwinter in Africa further south than Blackcaps (Cramp and Brooks 1992; for bird pictures, song recordings and sonograms see publicly available collections, e.g. Macaulay Library at the Cornell Laboratory of Ornithology or xeno-canto.org). They are closely related sister species that diverged about 6.3-6.8 million years ago (Blondel et al. 1996). Blackcaps arrive at the breeding ground earlier in the spring and are able to drive later arriving Garden Warblers out of their breeding territories (Raines 1945; Garcia 1983).

Previous studies (Matyjasiak 2005) have suggested that the interspecific aggressive response of male Blackcaps to Garden Warbler intruders is based on the ability of these males to make associations between species-specific songs and plumage. Furthermore, male Blackcaps were able to remember and recall these associations after several months without contact with Garden Warblers, whose wintering areas are further south. The question remains open whether male Blackcaps acquire the ability to identify male Garden Warblers by social learning of species-specific traits during interactions with congeners in common habitat (during breeding territory defense), which is consistent with the 'learned interspecific aggression' hypothesis (Irwin and Price 1999; Peiman and Robinson 2010). To determine if such associations are in response to the presence of heterospecifics, the first step is to consider the presence of these associations in focal species in the absence of-or before contact with-the heterospecifics (Peiman and Robinson 2010). In the case of migratory species, such as the Blackcap and the Garden Warbler, this can be achieved by comparing the interspecific response of second-year old (hereafter SY) males in their first breeding season and without previous experience of defending the breeding territory and older (experienced, after-second-year, ASY) males in the period prior to the spring arrival of the other species.

I performed a playback experiment with male Blackcaps at a site where both warbler species are abundant and cooccur during breeding season, and at the time just before Garden Warblers returned from spring migration. I compared the agonistic response of male Blackcaps of known age to playbacks of songs of one or the other species and stuffed male models of both species presented simultaneously in their territories. If male Blackcaps learn to associate species-specific traits during their first breeding season (the 'learned interspecific aggression' hypothesis), I predicted that while ASY males would be able to associate speciesspecific song with species-specific plumage types, SY males would be unable to do so and would direct their aggressive response to the conspecifics male model, regardless of the song being played back. If male Blackcaps make this association innately (the 'innate interspecific recognition hypothesis'), associations of species-specific traits should be observed in both SY and older individuals. If male Blackcaps do not discriminate between agonistic signals of Garden Warblers and their own species (the 'mistaken identity' hypothesis), associations should not be observed at all (although this scenario is unlikely, as shown earlier by Matyjasiak 2005).

\section{Methods}

\section{Field site and study species}

Fieldwork was conducted along the floodplain of the Vistula river valley, between Łomianki and Czosnów near Warsaw, central Poland (approximately $52.383^{\circ} \mathrm{N}, 20.809^{\circ} \mathrm{E}$ ). The study area extends for about $15 \mathrm{~km}$ along the flood terrace on the left Vistula riverbank, covering a total of $3.0 \mathrm{~km}^{2}$. The main landscape is a large lowland river valley (elevation about $80 \mathrm{~m}$ above sea level), which in the riverine zone is covered by a mosaic of fragmented poplar and willow riparian woods of different ages, willow or ash-leaved maple thickets, and grasslands, with a few larger patches of mature poplar and willow riparian forests. The areas lying on the higher floodplain terrace include agricultural land and human settlements separated from the river by flood embankments. Blackcaps and Garden Warblers are both common at the study area. They occupy riparian woods or 
shrubs with groups of trees, and their territories are often adjacent. The densities of these species are the lowest in a mosaic of fragmented poplar and willow woods, thickets and meadows (Blackcaps: 26 pairs per $\mathrm{km}^{2}$, Garden Warblers: nine pairs per $\mathrm{km}^{2}$ ) and reach the highest values in larger patches of mature poplar and willow forests with good undergrowth (Blackcaps: 226 pairs per km² ${ }^{2}$ Garden Warblers: 18 pairs per $\mathrm{km}^{2}$; Keller et al. 2017).

Blackcaps arrive at the study area between the beginning of April and mid May, and Garden Warblers arrive on average after 5th May. Playback experiments were conducted between 15th April and 5th May 2009, during the pre-nesting and early nesting stage in the breeding cycle of Blackcaps, before the arrival of Garden Warblers from wintering grounds. This enabled me to study SY male Blackcaps that had never defended their breeding territories against male Garden Warblers.

\section{Playback experiment}

I performed playback trials on 45 territorial male Blackcaps. Within the study site singing male Blackcaps were identified by daily walking through suitable habitats. The location and extent of their territories were then determined by 30 min of observation. To be classified as male's territory, the male had to remain within the area for the full $30 \mathrm{~min}$ of the observation period. The next day, if the territory was still occupied and the weather was favorable (without continuous rainfall or high winds), I performed the playback trial in it. In case the weather was inclement, the trial was performed a day or two later. Previously tested males were identified by the presence of leg rings (see below), and in addition, males occupying non-neighboring territories were chosen for the playback trials, which allowed me to avoid double testing the same individuals. Males were alternately assigned to trials with the song of Blackcaps (conspecific playback trials) and the song of Garden Warblers (heterospecific playback trials), with each male receiving only one song treatment (heterospecific or conspecific).
The playback experimental set-up was similar to that used by Matyjasiak (2005) and consisted of two stuffed male models (taxidermic dummies, mounted on $1.5 \mathrm{~m}$ tall sticks placed $4 \mathrm{~m}$ apart) and a loudspeaker (Anchor Mini-Vox model PB-25, 15 Watt, mounted on a $0.5 \mathrm{~m}$ plastic stake, pointing upwards and concealed under a camouflage net) placed between the male models at an equal distance from them (Fig. 1). These two models, one of a male Eurasian Blackcap and one of a Garden Warbler male, both in full breeding plumages and undamaged, represented a paired stimulus. Male models and the loudspeaker were placed well within the subject male's territory boundaries. A site was chosen where two low shrubs (willows, maples or elders) or short trees (willows or poplars) grew about 2-4 m apart with an empty space between them. Male models were placed by these shrubs or trees so that the subject had the possibility to perch near models, and a $1 \mathrm{~m}$ radius around each model was flagged with strips of yellow ribbon. The position of models with respect to side about the loudspeaker (as viewed from the observation point) was randomized. The area up to $6 \mathrm{~m}$ from the loudspeaker, flagged with white ribbon, is hereafter referred to as the test arena.

Then I played back either Garden Warbler or Blackcap territorial songs with a Sony D-SJ301 CD Walkman connected to the loudspeaker with a $20 \mathrm{~m}$ long $3.5 \mathrm{~mm}$ minijack audio cable, which allowed me to hide behind vegetation about $15 \mathrm{~m}$ from the loudspeaker. The volume when playing back songs was set by ear to achieve a naturalistic volume. Such a playback test was designed to mimic the territorial intrusion and advertisement of a male warbler. I terminated the playback immediately when the territory owner appeared at the test arena (within $6 \mathrm{~m}$ of the loudspeaker) looking for an intruder. The entire trial lasted $10 \mathrm{~min}$ from the onset of the song playback.

I measured the following variables: (1) latency to approach the test arena (accuracy of $1 \mathrm{~s}$ ); (2) time spent within the $1 \mathrm{~m}$ radius around the male model of the species whose song was being played (hereafter the correct model circle) and time spent within the $1 \mathrm{~m}$ radius around the other
Fig. 1 Playback experimental set-up. Schematic representation of the $6 \mathrm{~m}$ test arena, placement of the loudspeaker and male models, and correct and wrong model circles. Solid lines represent the test arena and $1 \mathrm{~m}$ radii around male models. Dashed lines show distances. Song playback ended immediately when the subject male appeared at the test arena

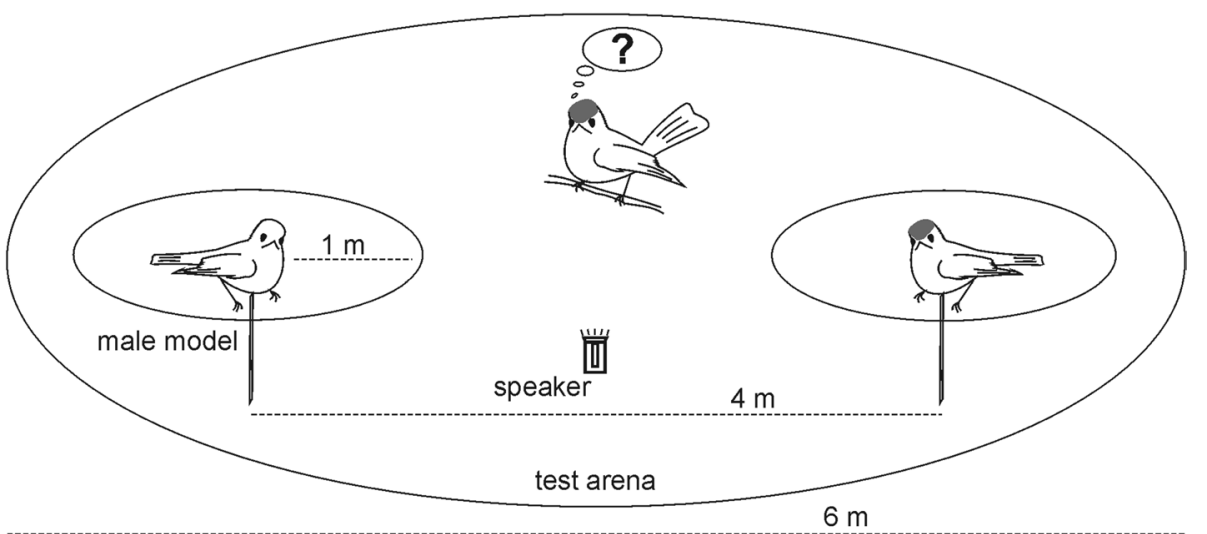


male model (hereafter the wrong model circle); (3) song rate- the number of songs per minute sung between the time the subject appeared at the test arena and the end of the trial (for raw data see Supplementary Online Materials). Song rate was measured only during the trial, not before the test since I often could not discriminate singing focal males from neighbors. Playback trials were performed in the morning, between 0600 and 1200. Each male Blackcap was tested only once.

As experimental stimuli, I used recordings of natural territorial songs of Blackcaps and Garden Warblers, recorded with a Telinga 5-PRO parabolic microphone and a Tascam DA-P1 portable DAT recorder (16 bit $/ 44.1-\mathrm{kHz}$ sampling rate WAV files), early in the morning, since mid-April through May 2001. All recordings were made from a distance of less than $15 \mathrm{~m}$, in forest or scrub habitats of the Kampinos Forest, 5-8 km from the present study area, each from a different individual. The recordings were free from distinct background singing, and were unedited. Each was arbitrarily numbered, and then used in playback trials in numerical order and only once to avoid pseudoreplication (Kroodsma 1989; Kroodsma et al. 2001).

Immediately after completing playback trials, I trapped the males by luring them with a playback of the conspecifics song into an ornithological mist-net (12 m long) set-up in the playback test arena. After capture males were aged, distinguishing SY males from ASY males on the basis of their molt patterns and feather quality (Jenni and Winkler 1994), ringed for further identification and released immediately. The percentage of first-year Blackcaps that may undergo complete post-juvenile molt, which would make them indistinguishable from ASY birds in spring, is very low in different populations of this species $(<2 \%$, Morganti et al. 2013). For this reason, it is likely that this potential error in aging (i.e. SY males incorrectly classified as ASY males by plumage) may not affect the results of the present study. Of the 45 two-choice song playback trials performed, 23 were heterospecific trials (16 on SY males and seven on ASY males) and 22 were conspecific trials (13 on SY males and nine on ASY males).

\section{Statistical analysis}

All statistical analyses were carried out in Statistica v.13 (TIBCO Software Inc., Palo Alto, CA) software, and nonparametric tests were applied. First, using the Wilcoxon signed-rank test I compared the time spent by focal males in correct and wrong model circles, separately for heterospecific and conspecific playback trials. I expected that if male Blackcaps associate species-specific songs with speciesspecific plumage they should spend significantly more time in the correct than in the wrong model circle.
Second, I calculated the differences in time spent by subjects in model circles (the time spent in the correct model circle minus the time spent in the wrong model circle). I used the Mann-Whitney $U$ test to compare these differences for SY and ASY males during heterospecific and conspecific playback trials. If SY male Blackcaps learn to associate species-specific traits during their first breeding season, I expected that during heterospecific playback trials, these males would spend more time in the wrong male circle or that they would spent a similar amount time in both model circles.

Finally, using the Kruskal-Wallis one-way ANOVA on ranks, I tested whether three behavioral variables characterizing the intensity of response to song playbacks-latency to approach the test arena, time spent in the right model circle, and song rate-differed significantly as a function of the age of the subject males and the species whose song was played back.

\section{Results}

All 45 subject male Blackcaps entered at least one of the two circles in which heterospecific or conspecific male models were presented simultaneously during playback trials. Typically the males approached the models while wing-flicking, singing and sometimes giving tac-tac calls. I did not observe physical attacks on the models.

Overall, male Blackcaps spent more time around the male model of the species whose song was being played than around the model of the other species, and specifically, SY and ASY males did not differ significantly in this regard. In heterospecific playback trials males spent significantly more time in the correct than in the wrong model circle (Wilcoxon signed-rank test, $Z=3.22, n=23, p=0.0012$; Fig. 2a). In this group, $13 \mathrm{SY}$ males spent more time in the correct model circle and $3 \mathrm{SY}$ males spent more time in the wrong model circle, while all 7 ASY males spent more time in the correct model circle. Furthermore, SY and ASY males did not differ significantly in their tendency to spend more time in the correct than in the wrong model circle (Mann-Whitney $\mathrm{U}$ test, $Z=0.0, n=16, m=7, p=1.0)$. Similarly, in conspecific playback trials subjects spend significantly more time in the correct than in the wrong model circle (Wilcoxon signedrank test, $Z=4.11, n=22, p<0.0001$; Fig. 2b). All $13 \mathrm{SY}$ males and all 9 ASY males spent more time in the correct than in the wrong model circle. Here, SY and ASY males did not differ significantly in their tendency to spend more time in the correct than in the wrong model circle (Mann-Whitney $U$ test, $Z=1,60, n=13, m=9, p=0.1$ ).

The intensity of male Blackcaps' response to song playback did not vary significantly with male age or whether the song of their own species or the song of Garden Warblers 

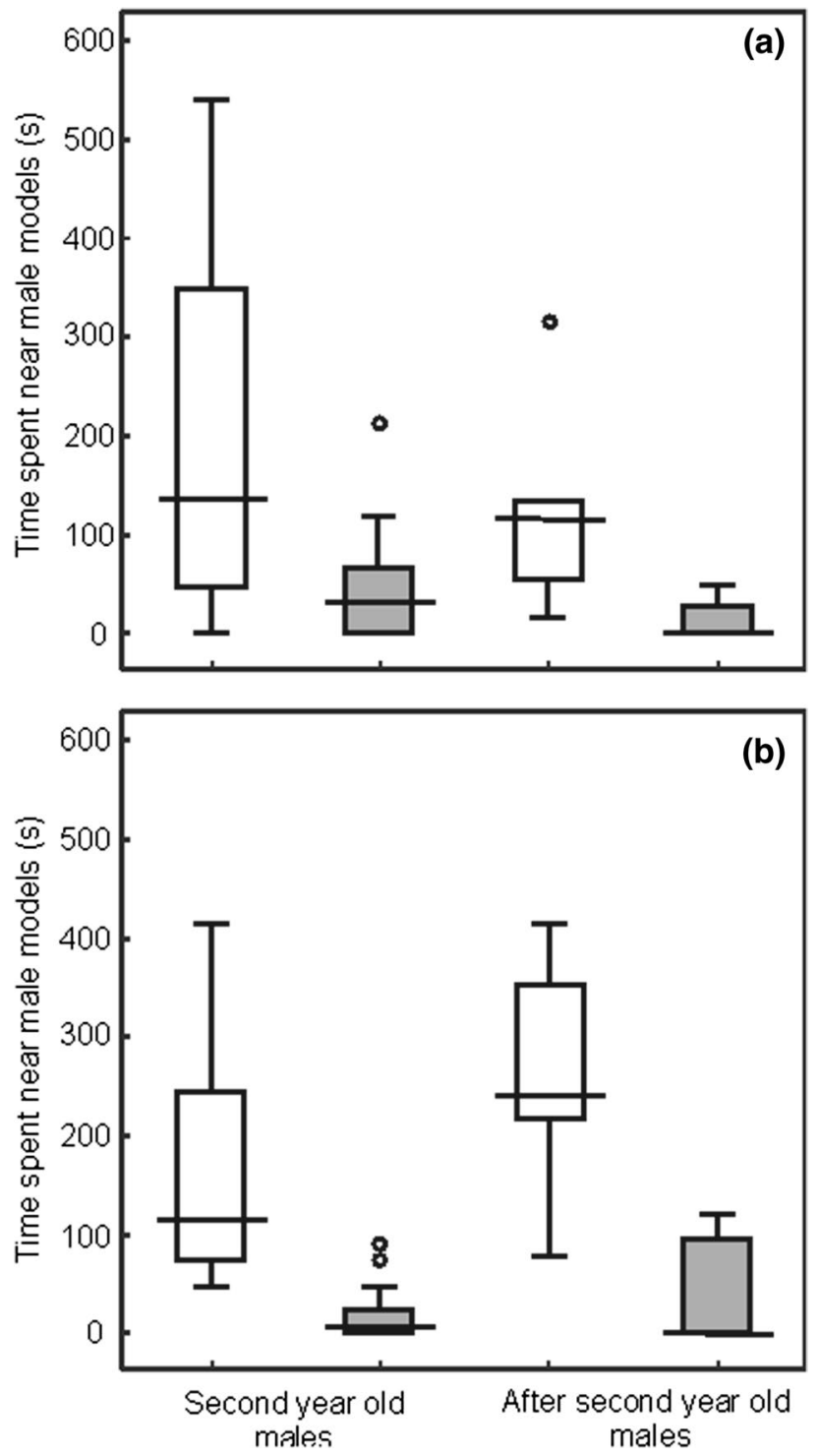

Fig. 2 Time spent by male Eurasian Blackcaps of different ages near models of Garden Warbler and conspecifics males during heterospecific (Garden Warbler) song playback trials (a) and conspecific song playback trials (b). White box plots refer to time spent by subject males near the male model of the species whose song was being played back during the trial (the correct male model) and gray box plots refer to time spent by males near the model of the other species (the wrong male model). The horizontal midlines within the boxes represent the median value. Boxes depict the first (Q1) to second quartile $(\mathrm{Q} 3)$ range of the data, and the whiskers extend 1.5 times beyond the interquartile range (IQR). Circles indicate outlier values above Q3+1.5 × IQR

was played back. There were no statistically significant differences in latency to approach the test zone, time spent in the correct model circle or song rate response variables among male age groups and song playback treatments (Kruskal-Wallis one-way analysis of variance, latency to approach the test zone: $H_{3}=2.38, n=45, p=0.50$; time
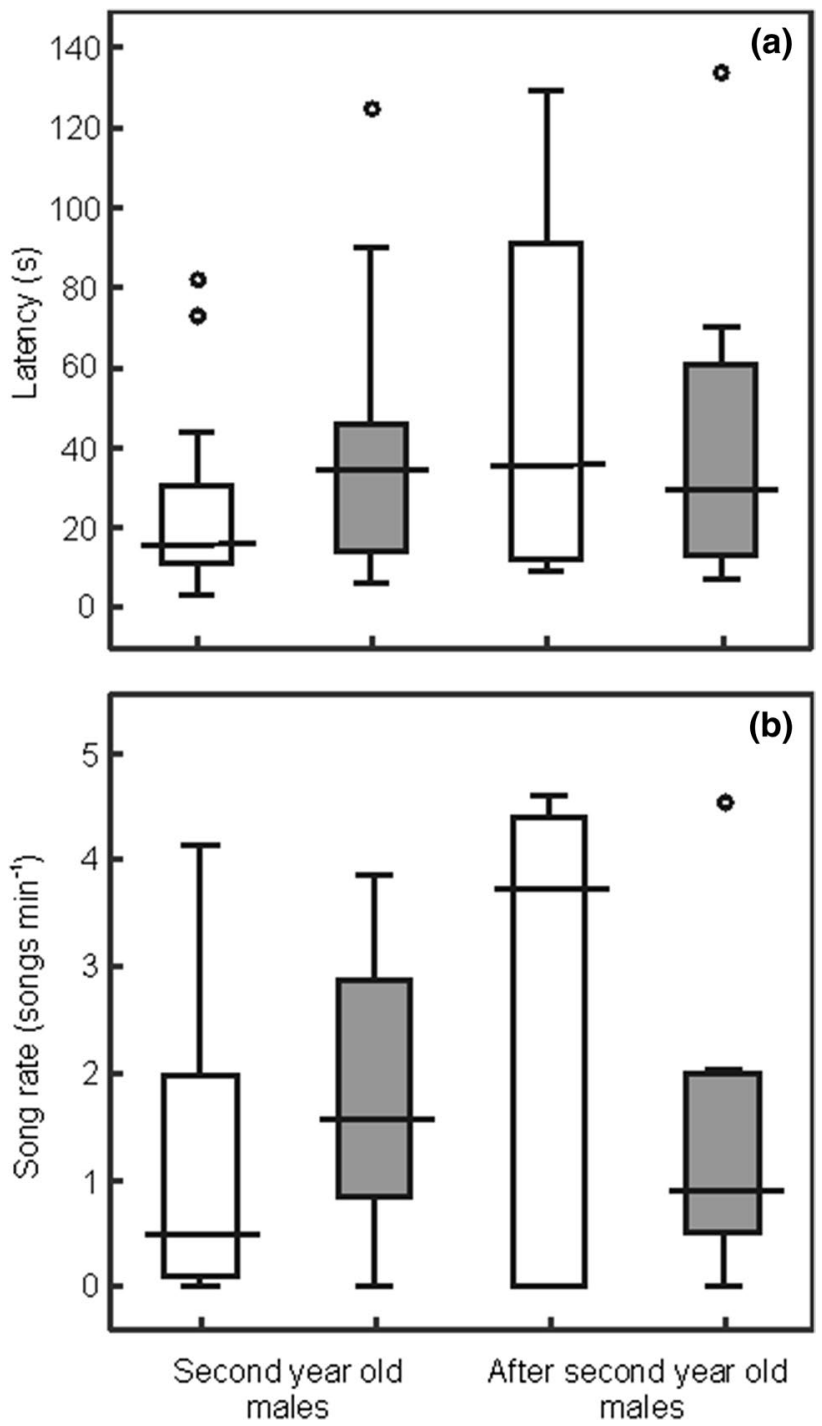

Fig. 3 Behavioral response intensity of male Eurasian Blackcaps of different ages to song playback as expressed by latency to approach the test arena (a) and song rate (b). White box plots refer to males' response to heterospecific song playbacks and gray box plots refer to males' response to conspecific song playbacks. The horizontal midlines within the boxes represent the median value. Boxes depict the first $(\mathrm{Q} 1)$ to second quartile $(\mathrm{Q} 3)$ range of the data, and the whiskers extend 1.5 times beyond the interquartile range (IQR). Circles indicate outlier values above $\mathrm{Q} 3+1.5 \times \mathrm{IQR}$

spent in the correct model circle: $H_{3}=4.84, n=45, p=0.18$; song rate: $H_{3}=3.52, n=45, p=0.32$; Figs. 2and3).

\section{Discussion}

Using a two-choice song playback experiment, I investigated whether male Eurasian Blackcaps are able to associate species-specific songs and species-specific plumage when identifying conspecific or Garden Warbler intruders in their 
breeding territories, and whether there are age-dependent differences between male Blackcaps in terms of this skill. I found that male Blackcaps, when looking for a rival in their territories and given a choice between two stuffed models of males (one of their own species and the other of the Garden Warbler), spent more time around the male model of the species whose song had been played back moments earlier. This suggests that these males were able to associate species-specific songs with species-specific plumage types. This ability characterized not only experienced ASY males, but also SY males that had not had the opportunity to defend breeding territories against Garden Warblers. This suggests that SY male Blackcaps acquire the ability to associate Garden Warbler song with plumage before they use this skill when defending territory during their first breeding episode. To my knowledge, this study is the first to test empirically whether such associations develop following territorial interactions with heterospecifics. Finally, I found that the intensity of male Blackcaps' behavioral responses to song playback did not differ depending on whether a song of their own species or Garden Warbler's song was being played back.

The present study, like the recent work by Darolová et al. 2020, showed that male Blackcaps respond as strongly to the playback of quite similar songs of the Garden Warbler as they do to the playback of conspecific songs. This finding corresponds well with previous studies showing that interspecific aggression by male Blackcaps results in exclusive territories defended against Garden Warblers (Raines 1945; Garcia 1983). This finding could also be consistent with the 'mistaken identity' hypothesis, according to which individuals cannot distinguish between heterospecific and conspecific signals (Murray 1971, 1981). However, as in previous studies (Matyjasiak 2005), here I showed that male Blackcaps are able to associate species-specific visual and auditory traits when recognizing conspecifics and heterospecifics. Male Blackcaps therefore do not mistake Garden Warblers for conspecifics, and the 'mistaken identity' hypothesis does not explain the existence of a response to heterospecific song in this species.

That male Blackcaps are able to associate species-specific visual and auditory signals might provide support for the 'learned interspecific aggression' hypothesis, according to which male birds learn to identify individuals of another species during regular encounters in the same habitat (Irwin and Price 1999; Price 2008; Grether 2011). According to the literature, males can learn these associations during interspecific competition for resources such as breeding territories, food supplies, nesting or roosting sites (Reed 1982; Catchpole and Leisler 1986; Gil 1997; Freeman 2016). But the major finding of this study is that SY male Blackcaps have the ability to associate Garden Warbler song with plumage even before they use it when defending their first ever breeding territories. However, this observation does not rule out the 'learned interspecific aggression' hypothesis as an explanation for the existence of interspecific aggressive response in male Blackcaps-learning in the subject males may have occurred earlier. At the same time, it does not exclude the possibility that the interspecific response in male Blackcaps has an innate component (the 'innate interspecific recognition hypothesis'), which would accelerate the associative learning (Price 2008). Or that male Blackcaps make this association innately (Grether 2011). In both cases, the fact that SY male Blackcaps arriving on the breeding grounds in spring already have the ability to identify Garden Warblers should be advantageous for this short-lived species, whose individuals can reproduce only for 1 or 2 breeding seasons on average (Cramp and Brooks 1992).

When and where do male Blackcaps acquire the ability to associate Garden Warbler song with plumage? If this ability is not innate, this may take place in the natal summer, during autumn or spring migration, or in a wintering area. Juvenile Blackcaps do not defend territories during their postfledging movements, and tend to track food supplies and congregate in places where there is an abundance of food (Chernetsov 2002). Meanwhile, in July and early August, the older Blackcap and Garden Warbler males continue to sing. In some birds, interspecific aggression by the dominant species continues into the fledgling period (e.g. Rice 1978). Juveniles can learn species-specific traits by eavesdropping on and watching older males contests, including heterospecific interactions (the 'eavesdropping hypothesis'). They may also initiate direct interactions with older males on their own (the 'direct interactions hypothesis', see e.g. Davies and Welbergen 2009; Templeton et al. 2010). Later on, starting with autumn migration, the learning opportunities seem to be fewer. First, there is only a slight overlap between the winter areas of Blackcaps and Garden Warblers. Blackcaps from central European breeding populations spend winter mostly in the Mediterranean or in north Africa (Cramp and Brooks 1992; Hiemer et al. 2018). Garden Warblers winter further south, in the sub-Saharan Africa (Cramp and Brooks 1992; Urban et al. 1997). However, some Blackcaps from central European populations may travel as far south as the Afrotropic, where north European populations of this species typically winter, and where they can meet Garden Warblers during wintering (Cramp and Brooks 1992; Mokwa 2004). Second, while some migratory bird species at least periodically defend territories during stopovers or on winter grounds (Stutchbury et al. 2005), Blackcaps and Garden Warblers rarely defend foraging territories during migration or wintering. At stopover sites or on wintering grounds both species are known to wander around, often in mixed-species groups, tracking ephemeral food sources (they are frugivorous-insectivorous during migration and wintering; Cramp and Brooks 1992; Urban et al. 1997). 
They tend to congregate in sites where food is plentiful, e.g. around fruiting trees or bushes, where a dominance structure may develop in which dominants chase subordinates away but do not use singing as an agonistic signal (Schaub and Jenni 2000; King and Hutchinson 2001; Belda et al. 2007; Salewski et al. 2007; Iwajomo et at. 2017). In the Mediterranean wintering area, sedentary individuals often defend their home ranges containing food sources from migrating or wintering conspecifics, but they do not sing while doing it (Pérez-Tris and Tellería 2002; Tellería and Pérez-Tris 2007; Morganti et al. 2017). In spring, males of both species may begin singing as early as during the migration, at stopovers (Cramp and Brooks 1992). However, opportunities for interspecific contact are unlikely during this period because Blackcaps migrate earlier than Garden Warblers (Rubolini et al. 2010).

Future research might resolve which of the scenarios described above is valid. The importance of innate mechanisms in the development of the associations of song with plumage can be investigated by performing double-choice song playback trials on male Blackcaps raised in captivity, which had or had not contact with congeners. The importance of social variables in associative learning might be investigated by tracking free living juvenile male Blackcaps during their natal summer months (e.g. Templeton et al. 2010; Snyder-Mackler and White 2011). The laboratory phase of such research could include experimentally arranging interactions between captive-bred juvenile Blackcap males and adult tutors. It would be important to investigate whether the association skills vary across development by testing male Blackcaps at various stages of their early life, from the phase shortly after fledging to about 10 months of age when the males return from Africa. Further research is also needed on whether the mechanism described here for identifying heterospecifics also applies to other bird species and how associations, if present, are formed.

Summing up, the present study shows that SY male Blackcaps acquire the ability to associate Garden Warbler song with plumage before using this ability to defend their breeding territories during the first breeding season. This suggests that these males do not mistake male Garden Warblers for males of their species, but rather learn these associations during the first months of life. However, this study does not exclude the possibility that these associations are innate.

Supplementary Information The online version contains supplementary material available at https://doi.org/10.1007/s10336-021-01901-0.

Acknowledgements I thank M. Wolsan, the Curator of the Natural History Museum (Museum and Institute of Zoology PAN), for allowing me to use stuffed birds in this study; J. Misiak, the Director of the Kampinos National Park, for permission to access the park area and make the recordings of warbler songs; and two anonymous reviewers for their helpful and constructive criticism of earlier versions of the manuscript. This work was supported by grants from the Foundation for Polish Science and the Ministry of Science and Higher Education of the Republic of Poland under Grant No. 2P04F07030.

Funding This work was supported by grants from the Foundation for Polish Science and the Ministry of Science and Higher Education of the Republic of Poland under Grant No. 2P04F07030.

Availability of data and material The data that support this work are available from the author on reasonable request.

\section{Declarations}

Conflict of interest The author declares there is no conflict of interest directly or indirectly related to the content of the submitted work.

Ethics approval The experiment conducted in this study complied with animal welfare laws of Poland. Birds were caught and ringed on the basis of the bird ringing license No. 172/2008 issued by the Polish Bird Ringing Centre.

Consent for publication The author agrees to publish the work.

Open Access This article is licensed under a Creative Commons Attribution 4.0 International License, which permits use, sharing, adaptation, distribution and reproduction in any medium or format, as long as you give appropriate credit to the original author(s) and the source, provide a link to the Creative Commons licence, and indicate if changes were made. The images or other third party material in this article are included in the article's Creative Commons licence, unless indicated otherwise in a credit line to the material. If material is not included in the article's Creative Commons licence and your intended use is not permitted by statutory regulation or exceeds the permitted use, you will need to obtain permission directly from the copyright holder. To view a copy of this licence, visit http://creativecommons.org/licenses/by/4.0/.

\section{References}

Belda EJ, Barba E, Monros JS (2007) Resident and transient dynamics, site fidelity and survival in wintering Blackcaps Sylvia atricapilla: evidence from capture-recapture analyses. Ibis 149:396-404. https://doi.org/10.1111/j.1474-919X.2007.00657.x

Blondel J, Catzeflis F, Perret P (1996) Molecular phylogeny and the historical biogeography of the warblers of the genus Sylvia (Aves). J Evol Biol 9:871-891. https://doi.org/10.1046/j.14209101.1996.9060871.x

Catchpole CK (1978) Interspecific territorialism and competition in Acrocephalus warblers as revealed by playback experiments in areas of sympathy and allopatry. Anim Behav 26:1072-1080. https://doi.org/10.1016/0003-3472(78)90096-9

Catchpole C, Leisler B (1986) Interspecific territorialism in reed warblers: a local effect revealed by playback experiments. Anim Behav 34:299-300

Chernetsov N (2002) Spatial behaviour of first-year Blackcaps (Sylvia atricapilla) during the pre-migratory period and during autumn migratory stopovers. J Ornithol 143:424-429. https:// doi.org/10.1007/BF02465597

Cramp S, Brooks DJ (1992) The birds of the Western Palaearctic. Warblers, vol VI. Oxford Univ. Press, Oxford 
Darolová A, Krištofík J, Knauer F, Hoi H (2020) Behavioural response of Eurasian Blackcaps to acoustically simulated conspecific and heterospecific male intruders. J Ornithol 161:447458. https://doi.org/10.1007/s10336-019-01743-x

Davies NB, Welbergen JA (2009) Social transmission of a host defense against cuckoo parasitism. Science 324:1318-1320. https://doi.org/10.1126/science. 1172227

Drury JP, Cowen MC, Grether GF (2020) Competition and hybridization drive interspecific territoriality in birds. PNAS 117:1292312930. https://doi.org/10.1073/pnas.1921380117

Emlen ST, Rising JD, Thompson WL (1975) A behavioral and morphological study of sympatry in the Indigo and Lazuli buntings of the Great Plains. Wilson Bull 87:145-302

Freeman BG (2016) Strong asymmetric interspecific aggression between two sympatric New Guinean robins. Ibis 158:75-81. https://doi.org/10.1111/ibi.12318

Freeman BG, Class Freeman AM, Hochachka WM (2016) Asymmetric interspecific aggression in New Guinean songbirds that replace one another along an elevational gradient. Ibis 158:726737. https://doi.org/10.1111/ibi.12384

Freeman BG, Tobias JA, Schluter D (2019) Behavior influences range limits and patterns of coexistence across an elevational gradient in tropical birds. Ecography 42:1832-1840. https://doi. org/10.1111/ecog.04606

Garcia EFJ (1983) An experimental test of competition for space between blackcaps Sylvia atricapilla and garden warblers Sylvia borin in the breeding season. J Anim Ecol 52:795-805. https:// doi.org/10.2307/4454

Gil D (1997) Increased response of the Short-toed Treecreeper Certhia brachydactyla in sympatry to the playback of the song of the Common Treecreeper C. familiaris. Ethology 103:632641. https://doi.org/10.1111/j.1439-0310.1997.tb00174.x

Gill FB, Murray BG Jr (1972) Discrimination behavior and hybridization of the blue-winged and golden-winged warblers. Evolution 26:282-293. https://doi.org/10.2307/2407038

Grether GF (2011) The neuroecology of competitor recognition. Integr Comp Biol 51:807-818. https://doi.org/10.1093/icb/ icr060

Grether GF, Losin N, Anderson CN, Okamoto K (2009) The role of interspecific interference competition in character displacement and the evolution of competitor recognition. Biol Rev 84:617635. https://doi.org/10.1111/j.1469-185X.2009.00089.X

Grether GF, Anderson CN, Drury JP, Kirschel AN, Losin N, Okamoto K, Peiman KS (2013) The evolutionary consequences of interspecific aggression. Ann NY Acad Sci 1289:48-68. https://doi.org/ 10.1111/nyas. 12082

Grether GF, Peiman KS, Tobias JA, Robinson BW (2017) Causes and consequences of behavioral interference between species. Trends Ecol Evol 32:760-772. https://doi.org/10.1016/j.tree.2017.07.004

Hiemer D, Salewski V, Fiedler W, Hahn S, Lisovski S (2018) First tracks of individual Blackcaps suggest a complex migration pattern. J Ornithol 159:205-210. https://doi.org/10.1007/ s10336-017-1490-3

Irwin DE, Price T (1999) Sexual imprinting, learning and speciation. Heredity 82:347-354. https://doi.org/10.1038/sj.hdy.6885270

Iwajomo SB, Ottosson U, Thorup K (2017) Spatial behaviour and food choice of the Garden Warbler Sylvia borin during the nonbreeding season. Ostrich 88:19-25. https://doi.org/10.2989/00306 525.2016.1221477

Jankowski JE, Robinson SK, Levey DJ (2010) Squeezed at the top: interspecific aggression may constrain elevational ranges in tropical birds. Ecology 91:1877-1884. https://doi.org/10.1890/ 09-2063.1

Jenni L, Winkler R (1994) Moult and ageing of European passerines. Academic Press, London
Jones JA, Tisdale AC, Tucker JL, Bakermans MH, Larkin JL, Smalling CG, Siefferman L (2016) A case of mistaken identity: understanding the stimulus of agonism between two wood warblers. Anim Behav 114:81-91. https://doi.org/10.1016/j.anbehav.2016.01.024

Keller M, Dmoch A, Malina R, Okołów G, Tusiński R (2017) Bird communities of riparian forests and groves of the Middle Vistula River Valley. In: Keller M, Kot H, Dombrowski A, Rowiński P, Chmielewski S, Bukaciński D (eds) Birds of the Middle Vistula River. M-ŚTO, Pionki, pp 127-157

King JMB, Hutchinson JM (2001) Site fidelity and recurrence of some migrant bird species in The Gambia. Ring Migr 20:292-302. https://doi.org/10.1080/03078698.2001.9674255

Kroodsma DE (1989) Suggested experimental designs for song playbacks. Anim Behav 37:600-609. https://doi.org/10.1016/00033472(89)90039-0

Kroodsma DE, Byers BE, Goodale E, Johnson S, Liu WC (2001) Pseudoreplication in playback experiments, revisited a decade later. Anim Behav 61:1029-1033. https://doi.org/10.1006/anbe.2000. 1676

Losin N, Drury JP, Peiman KS, Storch C, Grether GF (2016) The ecological and evolutionary stability of interspecific territoriality. Ecol Lett 19:260-267. https://doi.org/10.1111/ele.12561

Martin PR, Montgomerie R, Lougheed SC (2015) Color patterns of closely related bird species are more divergent at intermediate levels of breeding-range sympatry. Am Nat 185:443-451. https:// doi.org/10.1086/680206

Matyjasiak P (2005) Birds associate species-specific acoustic and visual cues: recognition of heterospecific rivals by male blackcaps. Behav Ecol 16:467-471. https://doi.org/10.1093/beheco/ari012

McEntee JP (2014) Reciprocal territorial responses of parapatric African sunbirds: species-level asymmetry and intraspecific geographic variation. Behav Ecol 25:1380-1394. https://doi.org/10. 1093/beheco/aru136

Mokwa K (2004) The migration strategy of European populations of the Blackcap Sylvia atricapilla. PhD Dissertation, University of Gdańsk

Morganti M, Aguirre JI, Onrubia A, Pulido F (2013) Complete postjuvenile moult in first-year Blackcaps: proximate causes and adaptive implications. Ardeola 60:45-57. https://doi.org/10.13157/ arla.60.1.2012.45

Morganti M, Assandri G, Aguirre JI, Ramirez Á, Caffi M, Pulido F (2017) How residents behave: home range flexibility and dominance over migrants in a Mediterranean passerine. Anim Behav 123:293-304. https://doi.org/10.1016/j.anbehav.2016.10.021

Murray BG Jr (1971) The ecological consequences of interspecific territorial behavior in birds. Ecology 52:414-423. https://doi.org/ $10.2307 / 1937624$

Murray BG Jr (1981) The origins of adaptive interspecific territorialism. Biol Rev 56:1-22. https://doi.org/10.1111/j.1469-185X.1981. tb00341.x

Ord TJ, Stamps JA (2009) Species identity cues in animal communication. Am Nat 174:585-593. https://doi.org/10.1086/605372

Ord TJ, King L, Young AR (2011) Contrasting theory with the empirical data of species recognition. Evolution 65:2572-2591. https://doi.org/10.1111/j.1558-5646.2011.01319.x

Orians GH, Willson MF (1964) Interspecific territories of birds. Ecology 45:736-745. https://doi.org/10.2307/1934921

Peiman K, Robinson B (2010) Ecology and evolution of resourcerelated heterospecific aggression. Q Rev Biol 85:133-158. https://doi.org/10.1086/652374

Pérez-Tris J, Tellería JL (2002) Migratory and sedentary blackcaps in sympatric non-breeding grounds: implications for the evolution of avian migration. J Anim Ecol 71:211-224. https://doi.org/10. 1046/j.1365-2656.2002.00590.x

Petrusková T, Petrusek A, Pavel V, Fuchs R (2008) When an alien sings at a rival's post: a passerine excited by conspecific 
stimulus may show aggressive behaviour towards heterospecific individuals. Folia Zool 57:201-211

Prescott DR (1987) Territorial responses to song playback in allopatric and sympatric populations of Alder (Empidonax alnorum) and Willow (E. traillii) flycatchers. Wilson Bull 99:611-619

Price T (2008) Speciation in birds. Roberts \& Co, Greenwood Village, $\mathrm{CO}$

Raines RJ (1945) Notes on the territory and breeding behaviour of Blackcap and Garden Warbler. Brit Birds 38:202-204

Reed TM (1982) Interspecific territoriality in the chaffinch and great tit on islands and the mainland of Scotland: playback and removal experiments. Anim Behav 30:171-181. https://doi.org/ 10.1016/S0003-3472(82)80252-2

Reif J, Jiran M, Reifová R, Vokurková J, Dolata PT, Petrusek A, Petrusková T (2015) Interspecific territoriality in two songbird species: potential role of song convergence in male aggressive interactions. Anim Behav 104:131-136. https://doi.org/10. 1016/j.anbehav.2015.03.016

Rice JC (1978) Behavioural interactions of interspecifically territorial vireos. II. Seasonal variation in response intensity. Anim Behav 26:550-561. https://doi.org/10.1016/0003-3472(78) 90070-2

Robinson SK, Terborgh J (1995) Interspecific aggression and habitat selection by Amazonian birds. J Anim Ecol 64:1-11. https://doi. org/10.2307/5822

Rubolini D, Saino N, Møller AP (2010) Migratory behaviour constrains the phenological response of birds to climate change. Clim Res 42:45-55. https://doi.org/10.3354/cr00862

Salewski V, Almasi B, Heuman A, Thoma M, Schlageter A (2007) Agonistic behaviour of Palaearctic passerine migrants at a stopover site suggests interference competition. Ostrich 78:349-355. https://doi.org/10.2989/OSTRICH.2007.78.2.37.117

Schaub M, Jenni L (2000) Fuel deposition of three passerine bird species along the migration route. Oecologia 122:306-317. https:// doi.org/10.1007/s004420050036

Sedláček O, Cikánová B, Fuchs R (2006) Heterospecific rival recognition in Black Redstart (Phoenicurus ochruros). Ornis Fenn 83:153-161
Simpson RK, Wilson DR, Mistakidis AF, Mennill DJ, Doucet SM (2021) Sympatry drives colour and song evolution in wood-warblers (Parulidae). P Roy Soc B-Biol Sci 288:20202804. https:// doi.org/10.1098/rspb.2020.2804

Snyder-Mackler N, White D (2011) The developmental ecology of acoustic reactions: approaches to song playbacks by male cowbirds change across their first year of life. Behaviour 148:747-764. https://doi.org/10.1163/000579511X575951

Stutchbury BJM, Morton ES, Pitcher TE (2005) Sex roles in migrants. Extra-pair mating systems and winter social systems. In: Greenberg R, Marra PP (eds) Birds of two worlds. The Johns Hopkins University Press, Baltimore, pp 307-320

Telleria JL, Pérez-Tris J (2007) Habitat effects on resource tracking ability: do wintering blackcaps Sylvia atricapilla track fruit availability? Ibis 149:18-25. https://doi.org/10.1111/j.1474-919X. 2006.00590.x

Templeton CN, Akçay Ç, Campbell SE, Beecher MD (2010) Juvenile sparrows preferentially eavesdrop on adult song interactions. $\mathrm{P}$ Roy Soc B-Biol Sci 277:447-453. https://doi.org/10.1098/rspb. 2009.1491

Tobias JA, Cornwallis CK, Derryberry EP, Claramunt S, Brumfield RT, Seddon N (2014) Species coexistence and the dynamics of phenotypic evolution in adaptive radiation. Nature 506:359-363. https://doi.org/10.1038/nature12874

Urban EK, Fry CH, Keith S (1997) The birds of Africa, vol 5th. Academic Press, San Diego

Wolfenden A, Jones CG, Tatayah V, Züel N, de Kort SR (2015) Endangered pink pigeons treat calls of the ubiquitous Madagascan turtle dove as conspecific. Anim Behav 99:83-88. https://doi.org/10. 1016/j.anbehav.2014.10.023

Publisher's Note Springer Nature remains neutral with regard to jurisdictional claims in published maps and institutional affiliations. 